\title{
Kesesuaian Uji Cepat Antigen Mycobacterium tuberculosis dengan Pulasan BTA pada Tersangka Tuberkulosis Paru
}

\author{
Nila Rahma Suryani ${ }^{1}, \mathrm{H}$. Lillah², Eugeny Alia ${ }^{2}$
}

\begin{abstract}
Abstrak
Tuberkulosis (TB) merupakan penyakit infeksi menular disebabkan oleh M. tuberculosis yang apabila tidak diobati atau pengobatannya tidak tuntas dapat menimbulkan komplikasi bahkan kematian. Menegakkan diagnosis TB yang cepat dan akurat membutuhkan pemeriksaan yang cepat. Penelitian ini bertujuan mengetahui kesesuaian uji cepat antigen M. tuberculosis dengan pulasan BTA. Penelitian ini merupakan penelitian analitik dengan rancangan potong lintang yang dilakukan di Laboratorium Sentral RSUP Dr. M. Djamil Padang dari bulan April 2016 sampai dengan September 2016. Sampel sputum tersangka TB diperiksa menggunakan uji cepat antigen M. tuberculosis dengan prinsip immunochromatography dan pulasan BTA dengan pewarnaan Ziehl-Neelsen. Sampel penelitian sebanyak 23 dilakukan uji cepat antigen M. tuberculosis didapatkan $9(39,1 \%)$ positif dan $14(60,9 \%)$ negatif. Pulasan BTA didapatkan $6(26,1 \%)$ positif dan $17(73,9 \%)$ negatif. Uji kesesuaian antara uji cepat antigen M. tuberculosis dengan pulasan BTA didapatkan nilai Kappa 0,321 $(p=0,108)$ dengan interpretasi cukup, tetapi tidak bermakna secara statistik ( $p>0,05)$. Tidak terdapat kesesuaian antara uji cepat antigen M. tuberculosis dengan pulasan BTA. Penelitian lebih lanjut diperlukan dengan jumlah sampel yang lebih banyak dan menggunakan baku emas sehingga didapatkan sensitivitas dan spesifisitas.
\end{abstract}

Kata kunci: Pulasan BTA, Tuberkulosis, Uji cepat antigen M. tuberculosis, Uji kesesuaian

\begin{abstract}
Tuberculosis is an infectious disease caused by M. tuberculosis, if not treated properly can be fatal. Rapid test is needed to diagnose TB accuratly. The aim of this study is to determine the agreement of M. tuberculosis antigen with acid fast bacilli smear. This was an analytic study with cross sectional design in Central Laboratorium Installation of Dr. M. Djamil Hospital Padang from April 2016 until September 2016. Rapid test for M. tuberculosis antigen is using immunochromatography method and acid-fast bacilli smear is using Ziehl Neelsen method, both of test were performed in suspected tuberculosis sputum sample. There were nine $(39,1 \%)$ positive, $14(60,9 \%)$ negative with rapid test, and six (26,1\%) positive, 17 (73,9\%) negative with acid fast bacilli smear. Kappa coefficient of agreement between $M$. tuberculosis antigen rapid test and acid-fast bacilli smear is $0,321 \quad(p=0,108)$ with fair agreement interpretation but not statisticaly significant. There is no agreement between $M$. tuberculosis antigen rapid test and acid-fast bacilli smear. Further research is needed with large sample and using gold standard method.
\end{abstract}

Keywords: Acid fast bacilli smear, Agreement test, M. tuberculosis antigen rapid test, Tuberculosis

Affiliasi penulis: 1. Program Pendidikan Dokter Spesialis Patologi Klinik Fakultas Kedokteran Universitas Andalas/Rumah Sakit Umum Pusat Dr. M. Djamil, Padang; 2. Bagian Patologi Klinik Fakultas Kedokteran Universitas Andalas/Rumah Sakit Umum Pusat Dr. M. Djamil, Padang

Korespondensi: Nila Rahma Suryani email : ynilarahma@yahoo.com Telp: 08126725106

\section{PENDAHULUAN}

Tuberkulosis (TB) merupakan penyakit infeksi menular yang disebabkan oleh bakteri M. tuberculosis, yang dapat menyerang semua organ, terutama paru. Tuberkulosis bila tidak diobati atau pengobatannya tidak tuntas, dapat menimbulkan komplikasi sampai menimbulkan kematian. ${ }^{1}$ Word health organization (WHO) tahun 2014 melaporkan terdapat enam juta kasus TB baru di dunia, lebih rendah dua pertiga dari 9,6 juta yang diperkirakan $\mathrm{WHO}^{2}$ Indonesia saat ini berada pada peringkat kelima negara dengan beban TB tertinggi di dunia. Estimasi prevalensi TB semua kasus adalah 660.000 kasus dan estimasi insedensi 430.000 kasus baru pertahun. Jumlah kematian akibat
TB diperkirakan 61.000 pertahun. ${ }^{3}$

Diagnosis TB ditegakkan berdasarkan gambaran klinis, pemeriksaan fisik, gambaran radiologis, pemeriksaan laboratorium dan pemeriksaan mikrobiologi. Pemeriksaan mikrobiologi yaitu identifikasi mikroorganisme dalam sekret atau jaringan pasien yang merupakan hal utama dalam mendiagnosis TB, meskipun pemeriksaan tersebut sulit dan mempunyai keterbatasan..$^{4,5}$

Baku emas identifikasi M. tuberculosis ialah kultur dengan media Lowenstein-Jensen (LJ) untuk diagnosis pasti yang memiliki sensitivitas $99 \%$ dan spesifisitas $100 \%$, namun memerlukan waktu sampai delapan minggu dan diperlukan sekitar 50-100 kuman hidup/mL sputum. 6,7 Pemeriksaan mikroskopis BTA sputum memegang peran dalam diagnosis awal dan pemantauan pengobatan TB paru. Rangkaian kegiatan yang baik diperlukan untuk mendapatkan hasil yang akurat, mulai dari cara pengumpulan sputum, pemilihan bahan sputum yang akan diperiksa dan pengolahan sediaan di bawah mikroskop. Teknik pewarnaan yang digunakan adalah Ziehl Neelsen 
yang dapat mendeteksi BTA dengan menggunakan mikroskop. ${ }^{8}$

Kriteria menegakkan diagnosis TB saat ini adalah berdasarkan pulasan BTA, tetapi kurang sensitif karena hasil baru positif bila terdapat kuman M. tuberculosis $>10^{3}$ organisme/mL sputum. Teknik diagnosis TB baru yang lebih cepat dan akurat sangat diperlukan untuk menegakkan diagnosis dan memulai terapi. 6,7

Metode pemeriksaan immuno chromatography (ICT) mempunyai beberapa keuntungan, diantaranya cepat, mudah, praktis, dan tidak memerlukan keahlian khusus. Teknik ini telah dikembangkan untuk mendeteksi antigen TB dengan menggunakan kombinasi tiga antibodi monoklonal untuk mendeteksi antigen TB spesifik ESAT6, CFP10 dan MPT64 yang disekskresikan oleh $M$. tuberculosis pada masa aktifnya. ${ }^{9}$ Penelitian di Rumah Sakit Dr. Hasan Sadikin Bandung mendapatkan sensitivitas dan spesifisitas dari uji cepat antigen $M$. tuberculosis masing-masing 95,7\% dan 87,2\%. ${ }^{10}$ Penelitian yang dilakukan Sari tahun 2010 mendapatkan sensitivitas dan spesifisitas uji cepat antigen $M$. tuberculosis masing-masing $72,6 \%$ dan $90,9 \% .{ }^{11}$

Deteksi antigen TB telah dikembangkan melalui temuan antigen spesifik yang berasal dari protein yang disekresi oleh $M$. tuberculosis. Antigen protein tersebut adalah early secretory antigenic target 6 (ESAT6), culture filtrate protein 10 (CFP10), dan Mycobacterium protein tuberculosis 64 (MPT64), yang disandi oleh gen region of diffences 1 (RD1), RD2, dan RD3. Ketiga antigen tersebut disekresi oleh $M$. tuberculosis saat bakteri hidup. Adanya antigen ini pada spesimen sputum penderita merupakan penanda terjadinya infeksi tuberkulosis paru aktif.9,12

Metode ICT menggunakan kombinasi tiga antibodi monoklonal terhadap antigen spesifik ESAT6, CFP10, dan MPT64 yang dikode oleh RD1, RD2, dan RD3 dengan bahan pemeriksaan sputum tersangka penderita TB paru. ${ }^{9}$

Penelitian ini bertujuan untuk mengetahui kesesuaian uji cepat antigen $M$. tuberculosis dengan pulasan BTA pada pasien tersangka tuberkulosis paru.

\section{METODE}

Penelitian analitik dengan rancangan potong lintang, dilakukan di instalasi laboratorium sentral RSUP Dr. M. Djamil Padang mulai April 2016 sampai dengan September 2016. Populasi penelitian adalah sputum seluruh pasien tersangka tuberkulosis paru yang dikirim dari poli paru dan penyakit dalam RSUP Dr. M. Djamil Padang dengan sampel dipilih secara consecutive sampling. Kriteria inklusi adalah sputum dengan volume minimal $3,5 \mathrm{~mL}$, kekentalan mukoid, dan warna hijau kekuningan (purulen). Kriteria eksklusi adalah sampel hemaptoe. Jumlah sampel penelitian 23 sputum dengan tingkat kepercayaan 95\%, proporsi 0,5 , dan presisi penelitian 0,2 .

Sputum tersangka tuberkulosis $0,2 \mathrm{~mL}$ diencerkan dengan diluent dari kit sebanyak $1 \mathrm{~mL}$, dikocok selama 30 menit, kemudian diteteskan pada kaset $200 \mu \mathrm{L}$ (4 tetes), di baca setelah 15 menit oleh peneliti dan dua orang lain sebagai konfirmasi. Sputum tersangka tuberkulosis juga dibuat slide pulasan BTA dengan pewarnaan Ziehl Neelsen, dibaca di bawah mikroskop dengan minyak imersi. Slide pulasan BTA dibaca oleh peneliti dan analis yang sudah kompeten dalam pembacaan slide pulasan BTA.

Kesesuaian antara uji cepat antigen $M$. tuberculosis dengan pulasan BTA pada pasien tersangka tuberkulosis paru dianalisis dengan uji Kappa menggunakan program komputer.

\section{HASIL DAN PEMBAHASAN}

Sebanyak 23 sampel yang memenuhi kriteria inklusi dan eksklusi selama April-September 2016 dilakukan pemeriksaan uji cepat antigen $M$. tuberculosis dan pulasan BTA. Tabel 1 menyajikan karakteristik subjek penelitian.

Tabel 1. Karakteristik Subjek Penelitian

\begin{tabular}{lcc}
\hline \multicolumn{1}{c}{ Variabel } & $\mathbf{n}(\%)$ & Rerata (SD) \\
\hline $\begin{array}{l}\text { Jenis Kelamin } \\
\text { Laki-laki }\end{array}$ & $20(87)$ & \\
Perempuan & $3(13)$ & \\
Usia & & $56,78(11,90)$ \\
\hline
\end{tabular}

Tabel 1 menunjukkan jumlah sampel sputum dari laki-laki lebih banyak dari perempuan yaitu 20 (87\%), dengan usia antara $39-73$ tahun, rerata 56,78 (SD 11,90) tahun. Tabel 2 dan 3 memperlihatkan distribusi frekuensi hasil pemeriksaan pulasan BTA dan uji cepat antigen $M$. tuberculosis pada sputum tersangka tuberkulosis paru.

Tabel 2. Distribusi Frekuensi Hasil Pemeriksaan Pulasan BTA

\begin{tabular}{lcc}
\hline \multicolumn{1}{c}{ Pulasan BTA } & Jumlah & Persentase \\
\hline Positif & 6 & 26,1 \\
Negatif & 17 & 73,9 \\
Total & 23 & 100 \\
\hline
\end{tabular}

Tabel 3. Distribusi Frekuensi Hasil Uji Cepat Antigen M. tuberculosis

\begin{tabular}{lcc}
\hline \multicolumn{1}{c}{ Pulasan BTA } & Jumlah & Persentase \\
\hline Positif & 9 & 39,1 \\
Negatif & 14 & 60,9 \\
Total & 23 & 100 \\
\hline
\end{tabular}

Tabel 2 memperlihatkan jumlah sampel dengan BTA positif $(+)$ sebanyak $6(26,1 \%)$ dan negatif 17 (73,9\%). Tabel 3 memperlihatkan hasil dengan uji cepat antigen $M$. tuberculosis positif sebanyak $9(39,1 \%)$ dan negatif $14(60,9 \%)$. Tabel 4 menampilkan uji kesesuaian antara uji cepat antigen M. tuberculosis dengan pulasan BTA. 
Tabel 4. Uji Kesesuaian antara Uji Cepat Antigen M. tuberculosis dengan Pulasan BTA

\begin{tabular}{lclll}
\hline \multirow{2}{*}{ Jenis Pemeriksaan } & \multicolumn{2}{c}{ Pulasan BTA } & \multirow{2}{*}{ Kappa } & $p$ \\
\cline { 2 - 3 } & Positif & Negatif & & \\
\hline Uji Cepat Antigen & & & & \\
M. tuberculosis & 4 & 5 & 0,32 & 0,11 \\
Positif & $(44,4 \%)$ & $(55,6 \%)$ & & \\
& 2 & 12 & & \\
Negatif & $(14,3 \%)(85,7 \%)$ & & \\
& &
\end{tabular}

Tabel 4 menunjukkan nilai Kappa antara uji cepat antigen $M$. tuberculosis dengan pulasan BTA yaitu $0,32(p=0,11)$ dengan interpretasi cukup, namun tidak bermakna secara statistik.

Subjek pada penelitian ini sebagian besar adalah laki-laki, sesuai dengan yang dipaparkan kepustakaan dimana penyakit TB lebih banyak pada laki-laki dan perbedaan ini dapat dipengaruhi oleh prilaku yang akan memengaruhi perkembangan penyakit, misalnya merokok dan konsumsi alkohol yang akan menurunkan imunitas tubuh. ${ }^{13,14}$ Rerata usia subjek penelitian 56,78 tahun dengan standar deviasi 11,90 tahun. Kepustakaan menyebutkan bahwa perjalanan penyakit TB berupa infeksi primer yang pada dewasa akan terjadi reaktivasi apabila terjadi penurunan imunitas karena pekerjaan yang berat dengan asupan gizi tidak baik. ${ }^{15}$

Penelitian ini mendapatkan tidak terdapat kesesuaian antara uji cepat antigen $M$. tuberculosis dengan pulasan BTA. Penelitian di Bandung tentang uji validitas pemeriksaan uji cepat antigen $M$. tuberculosis terhadap baku emas mendapatkan sensitivitas dan spesifisitas uji cepat antigen $M$. tuberculosis masing-masing $95,7 \%$ dan $87,2 \%$, sedangkan sensitivitas dan spesifisitas pulasan BTA masing-masing $85,7 \%$ dan $94,2 \% .^{10}$ Tidak jauh berbeda dengan yang didapatkan pada penelitian di Bandung yaitu sensitivitas dan spesifisitas uji cepat antigen $M$. tuberculosis masing-masing $72,6 \%$ dan $90,9 \%$ sedang sensitivitas dan spesifisitas pulasan BTA $83,8 \%$ dan $96,3 \% .{ }^{11}$ Penelitian tentang kesesuaian yang sama dengan peneliti belum ada temukan.

Penelitian ini secara statistik tidak bermakna, kemungkinan dapat disebabkan karena jumlah sampel yang sedikit walaupun sudah memenuhi rumus jumlah sampel minimal. Hasil penelitian mendapatkan dua sampel positif pada pulasan BTA dan negatif pada uji cepat antigen $M$. tuberculosis, hal ini dapat terjadi karena adanya kerusakan epitop dari antibodi rekombinan yang menjadi epitop penangkap antigen M. tuberculosis pada alat. ${ }^{10}$ Setelah ditelusuri, ternyata hasil pulasan BTA $(++)$ yang uji cepat antigen $M$. tuberkulosis negatif, sehingga kemungkinan terjadinya prozone effect pada penelitian ini belum dapat disingkirkan. Pulasan BTA juga dapat mendeteksi micobacterium other than tuberculosis (MOTT), sedangkan uji cepat antigen $M$. tuberculosis spesifik untuk M. tuberculosis.
Kelemahan penelitian ini adalah uji yang dilakukan tidak dengan baku emas karena kultur LJ sebagai baku emas membutuhkan waktu yang cukup lama, biaya yang lebih besar, dan banyak faktor memengaruhi keberhasilan pemeriksaan kultur.

\section{SIMPULAN}

Tidak terdapat kesesuaian antara uji cepat antigen $M$. tuberculosis dengan pulasan BTA. Penelitian lebih lanjut diperlukan dengan jumlah sampel yang lebih banyak dan menggunakan baku emas sehingga didapatkan sensitivitas dan spesifisitas.

\section{DAFTAR PUSTAKA}

1. Pusdatin Kemenkes RI. Tuberkulosis: Temukan Obati Sampai Sembuh. Infodatin. Jakarta. 2015. hal: 1-8. Diunduh pada 14 Januari 2016.

2. WHO. Global TB Report 2015. 2015. $20^{\text {th }}$ ed. diunduh pada 13 Agustus 2016.

3. Kemenkes RI. Terobosan Menuju Akses Universal, dalam: Strategi Nasional Pengendalian TB di Indonesia 2010-2014. Jakarta. 2011. hal: 170. Diunduh pada 19 Agustus 2016.

4. Vincent V, Gutiérrez MC. Mycobacterium: Laboratory Characteristics of Slowly Growing Mycobacteria', In: Murray PR, Baron EJ, Jorgensen JH, Landry ML, Pfaller MA, editors. Manual of Clinical Microbiology. 9th ed. Washington DC: American Society for Microbiology. 2010. p: 573-88. Diunduh pada 8 Agustus 2016

5. Kemenkes RI. Pedoman Nasional Pengendalian TB. Jakarta. 2014. hal: 1-150. Diunduh pada 7 Agustus 2016

6. Farnia $P$, Mohammadi $F$, Mirsaedi M, Zarifi AZ, Tabatabee J, Bahadori M, et al. Bacteriological Follow-Up of Pulmonary Tuberculosis Treatment: A Study with a Simple Colorimetric Assay. Microbes and Infection. 2004. pp: 972-6. Volume 6 No. 11. Diunduh pada 7 Agustus 2016

7. Muzaffar R, Batool S, Azis A, Naqvi A, Rizvi A. Evaluation of the FASTPLAQUETB Assay for Direct Detection of Mycobacterium Tuberculosis in Sputum Specimens. Int J Tuberc Lung Dis. 2002. pp: 635-40. Volume 6 No. 7. Diunduh pada 5 Agustus 2016

8. Handayani TE. Pemeriksaan Mikroskopis BTA pada Sputum Pasien Diduga TB Paru di Balai Kesehatan Paru Masyarakat Wilayah Semarang pada bulan Maret - April 2011 [disertasi]. Semarang: Fakultas Kedokteran Universitas Muhammadiyah Semarang. 2011. Diunduh pada 8 Agustus 2016

9. Shen $\mathrm{GH}$, Chiou CS, Hu ST, Wu KM, Chen JH. Rapid Identification of the Mycobacterium Tuberculosis Complex by Combining the ESAT6/CFP-10 Immunochromatographic Assay and Smear Morphology. J Clin Microbiol. 2011. pp: 
902-7. Volume 49 No. 3. Diunduh pada 9 Agustus 2016.

10. Gustiani N, Parwati I, Tjandrawati A, Lismayanti L. Validitas Pemeriksaan Complex Spesific Antigen Mycobacterium Tuberculosis Region of Diffence 1-3 Metode Rapid Immunochromatography pada Sputum Penderita Tuberkulosis Paru. MKB. 2014. pp: 241-6. Volume 46 No. 4. Diunduh pada 1 Agustus 2016.

11. Sari SK, Aryati. Nilai Diagnostik Antigen TB dengan Rapid Test Device ( $\mathrm{Tb} \mathrm{Ag}$ ) untuk Tuberkulosis. Indonesian Journal Clinical Pathology and Medical Laboratory. 2012. pp: 161167. Volume 18 No. 3. Diunduh pada 10 Agustus 2016.

12. Parkash O, Singh BP, Pai M. Regions of Differences Encoded Antigens as Targets for Immunodiagnosis of Tuberculosis in Humans. Scand J Immunol. 2009. pp: 345-57. Volume 70 No. 4. Diunduh pada 5 Agustus 2016

13. Bhat J, Rao VG, Gopi PG, Yadav R, Selvakumar $\mathrm{N}$, Tiwari B, et al. Prevalence of Pulmonary Tuberculosis Amongst the Tribal Population of Madhya Pradesh, Central India. Int J Epidemiol. 2009. pp: 1026-32. Volume 38 No. 4. Diunduh pada 6 Agustus 2016.

14. Shin SS, Mathew TA, Yanova GV, Fitzmaurice GM, Livchits V, Yanov SA, et al. Alcohol Consumption Among Men and Women with Tuberculosis in Tomsk, Russia. Cent Eur J Public Health. 2010. pp: 132-8. Volume 18 No. 3. Diunduh pada 5 Agustus 2016

15. Sita-Lumsden A, Lapthorn G, Swaminathan R, Milburn HJ. Reactivation of Tuberculosis and Vitamin D Deficiency: The Contribution of Diet and Exposure to Sunlight. Thorax. 2007. pp: 1003-7. Volume 62 No. 11. Diunduh pada 10 Agustus 2016 